\section{Jurnal Dinamis \\ Vol. 9, No. 1, Bulan Tahun | 06-21 \\ ISSN : 0216-7492, e-ISSN : 2809-3410 \\ Homepage : https://talenta.usu.ac.id/dinamis}

\title{
ANALISA KOMPUTASIONAL SIFAT MEKANIK DAN FAKTOR KESELAMATAN PADA CONNECTING JOINT ALAT PEMANAN KELAPA SAWIT
}

\author{
Agung Bosar P Manik ${ }^{1 *}$, Muhammad Sabri ${ }^{2}$, Arif Fadillah Nasution ${ }^{3}$ \\ Departemen Teknik Mesin, Fakultas Teknik, Universitas Sumatera Utara \\ Jalan Dr. T. Mansyur No. 9, Padang Bulan, Kec. Medan Baru, Kota Medan, Sumatera Utara 20222, Indonesia \\ *Email: agungmanik16@yahoo.com
}

\begin{abstract}
ABSTRAK
Connecting joint berfungsi menyambungkan tiap batang pada alat pemanen kelapa sawit. Connecting joint dirancang memiliki dua jenis yaitu connecting joint otomatis dan connecting joint manual. Connecting joint dapat diatur kemiringannya. Tujuan dari penelitian ini untuk mengetahui pola dan nilai dari stress, strain, dan safety factor pada connecting joint. Prosedur Analisa dilakukan dengan cara simulasi pada connecting joint menggunakan aplikasi Autodesk inventor. Dari hasil simulasi yang dilakukan didapat kesimpulan semakin kemiringan joint mendekati $0^{0}$, Pola stress dari joint semakin meningkat, stress terbesar pada titik connecting joint manual sebesar 10,4 MPa dan pada connecting joint otomatis sebesar $6.6 \mathrm{MPa}$ sedangkan tegangan izinnya $110 \mathrm{MPa}$ sehingga masih dalam keadaan aman, Semakin kemiringan joint mendekati $0^{0}$, pola strain dari joint juga akan semakin meningkat, strain terbesar pada titik connecting joint manual sebesar 0,00015 dan pada connecting joint otomatis sebesar 0,000093. Semakin kemiringan joint mendekati $0^{0}$, pola safety factor dari joint tetap berada pada nilai maksimum sehingga masih dalam keadaan aman.
\end{abstract}

Kata kunci: Connecting joint, Stress, Strain, Safety factor, Autodesk inventor

\begin{abstract}
The connecting connection serves to connect each stem with the oil palm harvester. There are two types of connection connection, namely automatic connection connection and manual connection connection. The Connections are tiltable. The purpose of this study was to determine the patterns and values of stress, strain, and safety factors at the joint joints. The analysis procedure is performed by simulating the connecting connection using the Autodesk inventor application. From the simulation results it can be concluded that the slope of the connection is getting closer to 00, the voltage pattern of the connection increases, the largest stress on the manual connection is $10.4 \mathrm{MPa}$ and the automatic connection is $6.6 \mathrm{MPa}$, while the permitting voltage is $110 \mathrm{MPa}$ so that it is still in a safe condition, the more slope When the connection approaches 00, the strain pattern of the joint will also increase, the greatest strain at the manual connection point is 0.00015 and at the automatic connection point it is 0.000093. The more the slope of the connection approaches 00, the pattern of the connection security factor remains at its maximum value so that it is still in a safe state.
\end{abstract}

Keywords: Connecting joint, Stress, Strain, Safety factor, Autodesk inventor

\section{PENDAHULUAN}

Salah satu faktor yang paling banyak mempengaruhi pertumbuhan dan produktivitas kelapa sawit ini adalah faktor panen. Untuk memenuhi kebutuhan panen ini dibutuhkan sebuah peralatan sebagai sarana penunjang pekerjaan dalam hal pemanenan buah kelapa sawit, maka perlu adanya suatu alat bantu pemanenan untuk mempermudah pekerjaan yang dilakukan dan tentunya dengan mempertimbangkan masalah kesehatan dan keselamatan kerja serta ramah terhadap lingkungan. Sebelumnya memang sudah ada inovasi-inovasi mengenai peralatan pemanenan buah kelapa sawit ini tetapi masih banyak terdapat kelemahan-kelemahan. Oleh sebab itu peneliti merancang sebuah connecting joint pada alat pemanenan buah kelapa sawit untuk dapat mengatur kemiringan alat panen dengan mudah.

Pada pembuatan alat pemanen kelapa sawit ini, penulis menganalisa alat ini dengan sistem bongkar pasang. Dimana batang galah tersebut dibagi menjadi 3 batang. Batang yang pertama memiliki panjang 3 meter, batang yang ke 2 memiliki panjang 2 meter, batang yang ke 3 memiliki panjang 1 meter. Setiap batang tersebut dihubungkan oleh connecting joint. Connecting joint tersebut dibagi menjadi dua. 
Pertama ialah connecting joint yang menghubungkan batang satu dan batang dua. Connecting joint yang pertama ini dapat diatur secara manual kemiringan nya dengan 3 lobang poros. Sedangkan connecting joint yang kedua ialah yang menghubungkan batang yang ke dua dengan batang yang ke tiga. Connecting joint ini digerakkan oleh motor listrik, dan dapat diatur kemiringan nya dengan menekan tombol yang ada di gagang alat tersebut.

\section{TEORI DASAR}

\subsection{Motor Listrik}

Mekanisme kerja motor listrik untuk seluruh jenis motor secara umum sama ${ }^{[1]}$ Arus listrik dalam medan magnet akan memberikan gaya, jika kawat yang membawa arus dibengkokkan menjadi sebuah lingkaran / loop, maka kedua sisi loop, yaitu pada sudut kanan dari medan magnet, akan mendapatkan gaya pada arah yang berlawanan, pasangan gaya menghasilkan tenaga putar / torque untuk memutar kumparan, Motor-motor memiliki beberapa loop pada dinamonya untuk memberikan tenaga putaran yang lebih seragam dan medan magnetnya dihasilkan oleh susunan elektromagnetik yang disebut kumparan medan.

\subsection{Momen Gaya/ Torsi}

Momen gaya gerak translasi dan gerak rotasi pada sebuah benda hanya dapat terjadi jika ada gaya memengaruhi benda. Apabila gaya yang bekerja berupa tarikan atau dorongan yang diberikan pada arah poros maka gaya tersebut hanya mengakibatkan pergeseran pada benda atau disebut translasi. Apabila garis gaya tidak melalui poros atau titik tengah dari pusat rotasi menyebabkan suatu benda berotasi dan dapat menghasilkan momen gaya/torsi. Torsi merupakan hasil kali gaya dengan jarak titik terhadap gaya. Torsi merupakan besaran vektor. Secara umum, untuk menghitung torsi dapat menggunakan persamaan berikut [2]:

$$
\tau=\mathbf{F} \cdot \mathrm{r} .
$$

$$
\begin{aligned}
& \text { Dimana: } \\
& \boldsymbol{\tau}=\text { Torsi }(\mathrm{Nm}) \\
& \mathbf{F}=\operatorname{Gaya}(\mathrm{N}) \\
& \mathrm{r}=\operatorname{Jarak}(\mathrm{m})
\end{aligned}
$$

\subsection{Tegangan (Stress)}

Tegangan dalam suatu elemen mesin adalah besarnya gaya yang bekerja tiap satuan luas penampang. Pada umumnya tegangan adalah gaya dalam yang bekerja pada luasan yang kecil tak hingga pada sebuah potongan dan terdiri dari bermacam-macam besaran dan arah ${ }^{[3]}$. Tegangan dapat diketahui dengan melakukan pengujian, dan besarnya kekuatan sangat tergantung pada jenis material yang diuji.

\subsubsection{Tegangan Normal}

Tegangan normal adalah intensitas gaya yang bekerja normal (tegak lurus) terhadap irisan yang mengalami tegangan ${ }^{[4]}$. Bila gaya gaya luar yang bekerja pada suatu batang yang sejajar terhadap sumbu utamanya dan potongan batang penampang tersebut konstan, tegangan internal yang dihasilkan adalah sejajar pada sumbu-sumbu tersebut.

Kekuatan dari gaya tarik dapat diperoleh dengan melakukan percobaan uji tarik terhadap spesimen yang mempunyai luas penampang A dan panjang L, seperti Spesimen dijepit pada mesin uji, lalu diberikan gaya tarik berlawanan arah, hingga spesimen tersebut putus. Spesimen tersebut akan mengalami yang disebut pertambahan panjang $(\Delta \mathrm{L})$ dan pengecilan luas penampang pada bagian yang memiliki kekuatan yang lebih besar.

\subsubsection{Tegangan Geser}

Tegangan geser adalah tegangan yang bekerja sejajar dengan bidang pembebanan ${ }^{[4]}$. Tegangan geser terjadi jika suatu benda bekerja dengan dua gaya yang berlawanan arah, tegak lurus sumbu batang, tidak segaris gaya namun pada penampangnya tidak terjadi momen. Tegangan ini banyak terjadi pada konstruksi.

\subsection{Regangan (Strain)}

Perpanjangan per satuan luas disebut regangan (strain). Regangan adalah besaran yang tidak berdimensi, tetapi lebih baik kita memberinya memiliki dimensi meter per meter atau $\mathrm{m} / \mathrm{m}{ }^{[5]}$. Besaran regangan $\varepsilon$ sangat kecil, kecuali untuk beberapa bahan seperti karet. Bila regangan tersebut diketahui, 
maka deformasi total dari pembebanan aksial adalah $\varepsilon L$. Hubungan ini berlaku untuk setiap panjang ukur sampai beberapa deformasi lokal mengambil bagian pada skala yang cukup besar.

Pada kebanyakan logam, deformasi elastis hanya terjadi sampai regangan 0.005. Jika bahan berdeformasi melewati batas elastis, tegangan tidak lagi proporsional terhadap regangan.

\subsection{Faktor Keamanan (Safety factor)}

Safety factor adalah faktor yang menunjukkan tingkat kemampuan suatu bahan teknik menerima beban dari luar, yaitu beban tekan maupun tarik. Gaya yang diperlukan agar terjadi tingkat optimal bahan di dalam menahan beban dari luar sampai akhirnya menjadi pecah disebut dengan beban ultimate (ultimate load). Dengan membagi beban ultimate ini dengan luas penampang, kita akan memperoleh kekuatan ultimate (ultimate strength) atau tegangan ultimate (ultimate stress) dari suatu bahan. Untuk desain bagian-bagian struktur tingkat tegangan disebut tegangan ijin (alloweble stress) dibuat benar benar lebih rendah dari pada kekuatan ultimate yang diperoleh dari pengujian "statis". Hal ini penting untuk berbagai pertimbangan. Karena tegangan dikalikan luas sama dengan gaya, maka tegangan ijin dari ultimate dapat diubah dalam bentuk gaya atau beban yang diijinkan dan ultimate yang dapat ditahan. Tingkat ketidakpastian juga merupakan hal penting yang menentukan nilai faktor keamanan yang digunakan. Ada beberapa tingkat ketidakpastian yang harus dipertimbangkan untuk elemen yang mendapatkan beban statis yaitu tingkat ketidak pastian beban, tingkat ketidakpastian kekuatan material, tingkat ketidakpastian desain dan analisis, konsekuensi kegagalan keamanan manusia dan ekonomi. Selain itu faktor ekonomi atau biaya yang dibutuhkan juga merupakan pertimbangan utama dalam menentukan faktor keamanan. Angka numerik faktor keamanan yang disarankan sesuai dengan beberapa parameter dan tingkat ketidakpastian akan ditunjukkan pada Tabel 2.1.

Tabel 2.1 Faktor Keamanan Yang Disarankan Dalam Perancangan ${ }^{[6]}$

\begin{tabular}{|c|c|c|}
\hline No & $\begin{array}{l}\text { Faktor } \\
\text { Keamanan } \\
\text { disarankan }\end{array}$ & $\begin{array}{l}\text { Parameter dan tingkat } \\
\text { ketidakpastian }\end{array}$ \\
\hline 1 & $\mathrm{Sf}=1,25-1,5$ & $\begin{array}{l}\text { Kondisi terkontrol dan } \\
\text { tegangan yang bekerja } \\
\text { dapat ditentukan } \\
\text { dengan pasti. }\end{array}$ \\
\hline 2 & $\mathrm{Sf}=1,5-2,0$ & $\begin{array}{l}\text { Bahan yang sudah } \\
\text { diketahui, kondisi } \\
\text { lingkungan beban dan } \\
\text { tegangan yang tetap } \\
\text { dan dapat ditentukan } \\
\text { dengan mudah. }\end{array}$ \\
\hline 3 & $\mathrm{Sf}=2,0-2,5$ & $\begin{array}{l}\text { Bahan yang beroperasi } \\
\text { secara rata-rata dengan } \\
\text { Batasan beban yang } \\
\text { diketahui. }\end{array}$ \\
\hline 4 & $\mathrm{Sf}=2,5-3,0$ & $\begin{array}{l}\text { Bahan yang diketahui } \\
\text { tanpa mengalami tes. } \\
\text { Pada kondisi beban dan } \\
\text { tegangan rata-rata. }\end{array}$ \\
\hline 5 & $\mathrm{Sf}=3,0-4,5$ & $\begin{array}{l}\text { Bahan yang sudah } \\
\text { diketahui. Kondisi } \\
\text { beban, tegangan dan } \\
\text { lingkungan yang tidak } \\
\text { pasti. }\end{array}$ \\
\hline 6 & \multicolumn{2}{|c|}{$\begin{array}{l}\text { Beban berulang: angka angka yang } \\
\text { disarankan diatas dapat digunakan } \\
\text { tetapi dengan endurance limit sebagai } \\
\text { significant strength. }\end{array}$} \\
\hline 7 & \multicolumn{2}{|c|}{$\begin{array}{l}\text { Beban impak: angka-angka yang } \\
\text { disarankan di atas dapat digunakan } \\
\text { tetapi factor impak harus dimasukkan. }\end{array}$} \\
\hline 8 & \multicolumn{2}{|c|}{$\begin{array}{l}\text { Materia getas: angka-angka yang } \\
\text { disarankan di atas dikalikan dua untuk } \\
\text { material getas, dimana faktor }\end{array}$} \\
\hline
\end{tabular}




\section{HASIL DAN PEMBAHASAN}

\subsection{Besar Gaya Pada Simulasi Connecting joint}

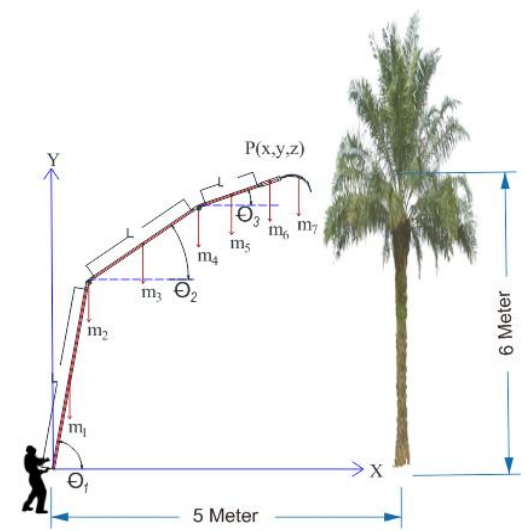

\section{Gambar 3.1 Sketsa Alat Pemanen Kelapa Sawit}

Tabel 3.1 Data Massa Dari Komponen Connecting Joint

\begin{tabular}{|l|l|l|}
\hline NO. & NAMA KOMPONEN & $\begin{array}{l}\text { HASIL } \\
\text { PENGUKURAN }\end{array}$ \\
\hline 1 & Pipa Galah Teleskopik (3 meter) & $1500 \mathrm{gr}$ \\
\hline 2 & Connecting joint manual & $1300 \mathrm{gr}$ \\
\hline 3 & Pipa Galah Teleskopik (2 meter) & $950 \mathrm{gr}$ \\
\hline 4 & Connecting joint otomatis & $2065 \mathrm{gr}$ \\
\hline 5 & Pipa Galah Teleskopik (1 meter) & $425 \mathrm{gr}$ \\
\hline 6 & Linear Actuator & $1800 \mathrm{gr}$ \\
\hline 7 & Pisau Egrek Sabit (Sickle) & $700 \mathrm{gr}$ \\
\hline
\end{tabular}

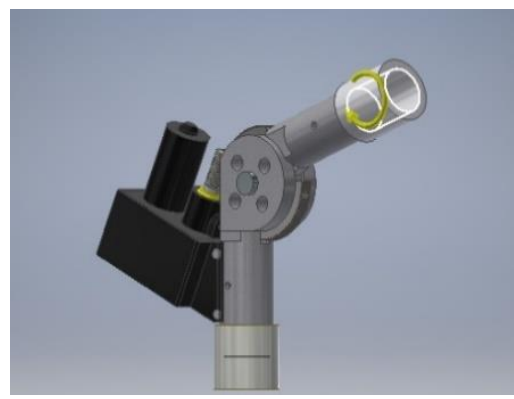

Gambar 3.2 Letak Gaya Pada Simulasi Connecting joint Otomatis

Seperti ditunjukkan pada Gambar 3.1 terdapat 3 benda yang mempengaruhi torsi pada joint yaitu pisau dengan massa $\mathrm{m}^{7}$, linear actuator dengan massa $\mathrm{m}^{6}$ dan batang 1 meter dengan massa $\mathrm{m} 5$. Nilai masing-masing m dapat dilihat pada Tabel 3.1.

Dengan menggunakan persamaan (2.1) diperoleh total torsi yang diinput pada joint otomatis.

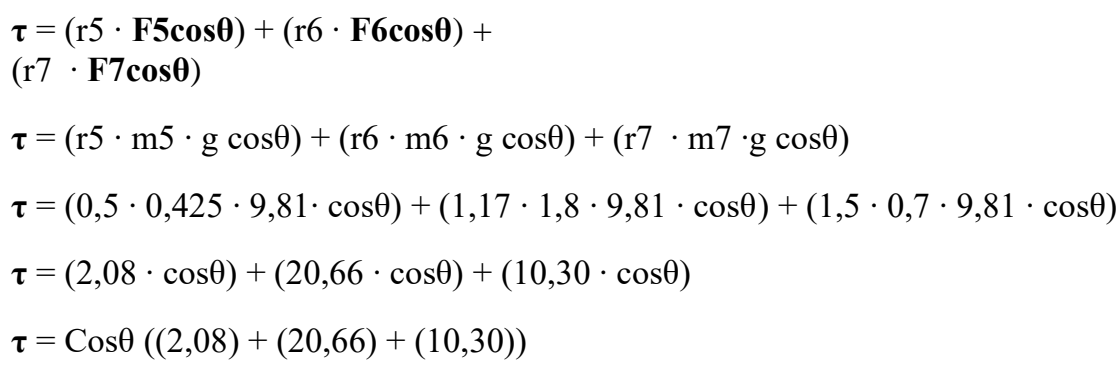


$\tau=\operatorname{Cos} \theta(33,04) \mathrm{Nm}$

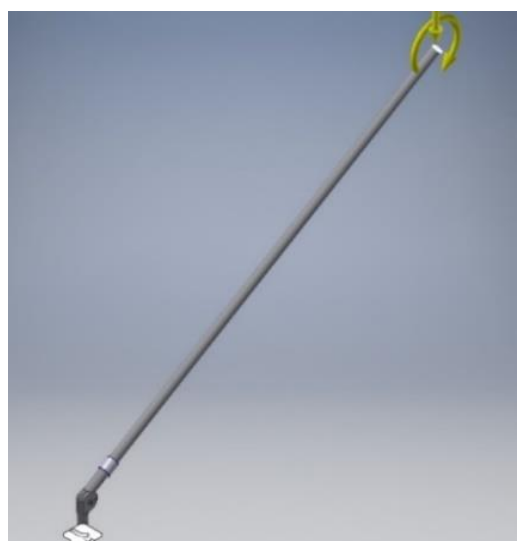

\section{Gambar 3.3 Letak Gaya Pada Simulasi Connecting joint Manual}

Pada joint manual terdapat 2 load yang diinput yaitu berat dari joint otomatis dan torsi. Seperti ditunjukkan Gambar 3.1 terdapat 4 benda yang mempengaruhi torsi pada joint yaitu pisau dengan massa $\mathrm{m} 7$, linear actuator dengan massa $\mathrm{m} 6$, batang 1meter dengan massa $\mathrm{m} 5$, dan berat dari joint otomatis dengan $\mathrm{m} 4$. Nilai masing-masing $\mathrm{m}$ dapat dilihat pada Tabel 3.1.

$\mathrm{F} 4=\mathrm{m}_{4} \cdot \mathrm{g}$

$\mathrm{F} 4=2,0625 \cdot 9,81$

$\mathrm{F} 4=20,23 \mathrm{~N}$

Dengan menggunakan persamaan (2.1) torsi yang diinput pada joint manual sama dengan torsi yang diinput pada joint otomatis yaitu:

$\boldsymbol{\tau}=(0,5 \cdot 0,425 \cdot 9,81 \cdot \cos \theta)+(1,17 \cdot 1,8 \cdot 9,81 \cdot \cos \theta)+(1,5 \cdot 0,7 \cdot 9,81 \cdot \cos \theta)$

$\boldsymbol{\tau}=(2,08 \cdot \cos \theta)+(20,66 \cdot \cos \theta)+(10,30 \cdot \cos \theta)$

$\boldsymbol{\tau}=\operatorname{Cos} \theta((2,08)+(20,66)+(10,30))$

$\tau=\operatorname{Cos} \theta(33,04) \mathrm{Nm}$

\subsection{Hasil Pengujian dan Analisis}

\subsubsection{Stress}

Stress yang diperhatikan pada connecting joint adalah $1^{\text {st }}$ principal stress atau yang biasa disebut dengan tegangan tarik akibat adanya pembebanan.

Tabel 3.2 Stress Analisis Pada Titik Connecting joint Otomatis

\begin{tabular}{|c|c|}
\hline Kemiringan $\left(^{(}\right)$ & Stress $(\mathrm{Mpa})$ \\
\hline 0 & 6,60 \\
\hline 10 & 6,10 \\
\hline 20 & 5,80 \\
\hline 30 & 5,50 \\
\hline 40 & 5,10 \\
\hline 50 & 4,01 \\
\hline 60 & 3,49 \\
\hline 70 & 2,38 \\
\hline 80 & 1,18 \\
\hline 90 & 0,001 \\
\hline
\end{tabular}


Jurnal Dinamis USU, Vol. 9, No. 1 (Bulan, Tahun) | 06-21

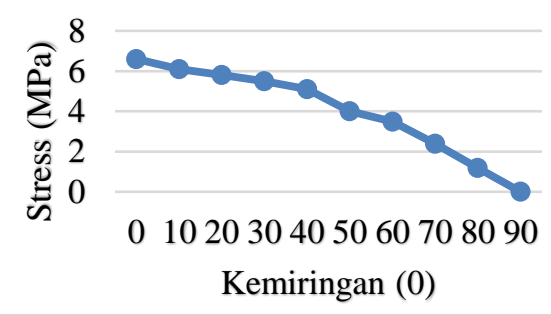

Gambar 3.4 Grafik Stress Analisis Pada Bagian Atas Connecting joint Otomatis

Tabel 3.3 Stress Analisis Bagian Atas Connecting joint Manual Pada Sudut 90

\begin{tabular}{|c|c|}
\hline $\begin{array}{c}\text { Kemiringan Connecting joint } \\
\text { Otomatis }\left({ }^{\circ}\right)\end{array}$ & Stress (Mpa) \\
\hline 0 & 4,39 \\
\hline 10 & 4,32 \\
\hline 20 & 4,12 \\
\hline 30 & 3,80 \\
\hline 40 & 3,35 \\
\hline 50 & 2,81 \\
\hline 60 & 2,18 \\
\hline 70 & 1,44 \\
\hline 80 & 7,36 \\
\hline 90 & 1,20 \\
\hline
\end{tabular}

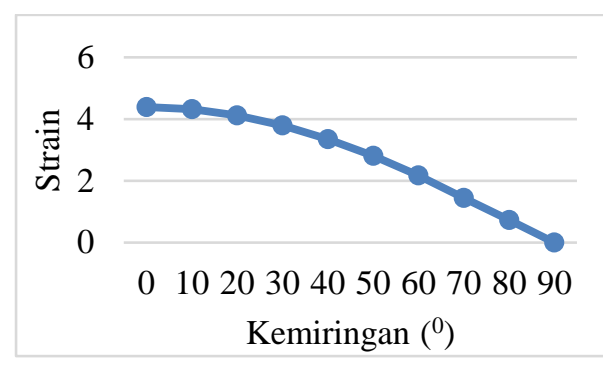

Gambar 3.5 Grafik Stress Analisis Bagian Atas Connecting joint Manual Pada Sudut 90 ${ }^{\circ}$

Tabel 3.4 Stress Analisis Pada Bagian Atas Connecting joint Manual Kemiringan 60 $^{0}$

\begin{tabular}{|c|c|}
\hline $\begin{array}{c}\text { Kemiringan } \\
\text { Connecting joint } \\
\text { Otomatis }\left({ }^{0}\right)\end{array}$ & Stress (Mpa) \\
\hline 0 & 8,11 \\
\hline 10 & 8,04 \\
\hline 20 & 7,82 \\
\hline 30 & 7,49 \\
\hline 40 & 7,03 \\
\hline 50 & 6,48 \\
\hline 60 & 5,83 \\
\hline
\end{tabular}




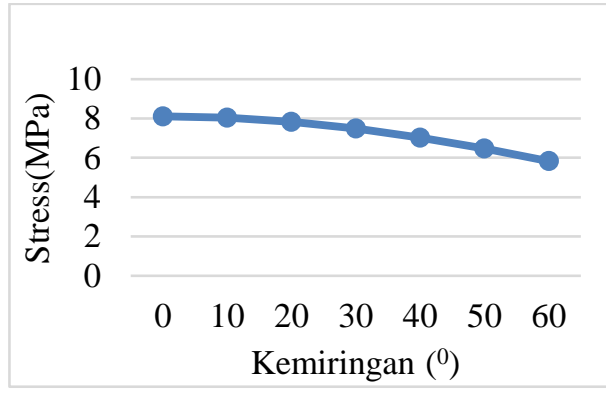

Gambar 3.6 Grafik Stress Analisis Bagian Atas Connecting joint Manual Kemiringan 60 $^{0}$

Tabel 3.5 Stress Analisis Pada Bagian Atas Connecting joint Manual Dengan Kemiringan $3^{\circ}$

\begin{tabular}{|c|c|}
\hline $\begin{array}{c}\text { Kemiringan Connecting } \\
\text { joint Otomatis }\left({ }^{0}\right)\end{array}$ & Stress $(\mathrm{Mpa})$ \\
\hline 0 & 10,40 \\
\hline 10 & 10,33 \\
\hline 20 & 10,13 \\
\hline 30 & 9,81 \\
\hline
\end{tabular}

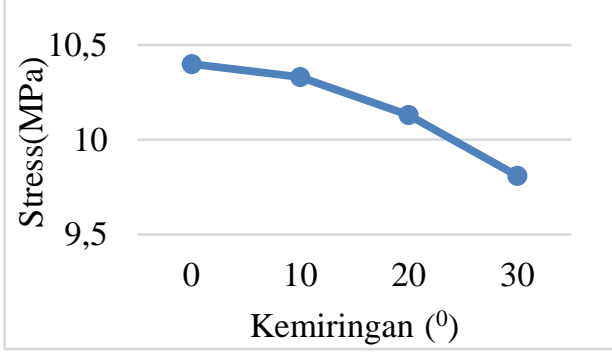

\section{Gambar 3.7 Grafik Stress Analisis Pada Bagian Atas Connecting joint Manual Dengan Kemiringan} $30^{0}$

Hasil dari simulasi stress dapat ditentukan stress terbesar dan terkecil pada bagian atas connecting joint manual dan bagian atas connecting joint otomatis.

1. Stress Tertinggi

a. Bagian atas Connecting joint otomatis

Stress Tertinggi berada pada kemiringan $0^{0}$ yaitu 6,6 MPa.

b. Bagian Atas Connecting joint Manual

Stress tertinggi berada saat joint manual berada pada lubang ke 3 yaitu kemiringan $30^{\circ}$ dan pada saat bersamaan connecting joint otomatis memiliki kemiringan $0^{0}$ yaitu $10,4 \mathrm{MPa}$.

2. Stress Terendah

a. Bagian atas Connecting joint otomatis

Stress Terendah berada pada kemiringan $90^{\circ}$ yaitu $0,001 \mathrm{MPa}$

b. Bagian Atas Connecting joint Manual

Stress tertinggi berada saat joint manual berada pada lubang ke 1 yaitu kemiringan $90^{\circ}$ dan pada saat bersamaan connecting joint otomatis memiliki kemiringan $90^{\circ}$ yaitu 0,0012 MPa.

\subsubsection{Strain Analisis}

Strain yang diperhatikan pada connecting joint adalah $1^{\text {st }}$ principal strain atau yang biasa disebut dengan regangan Tarik akibat adanya pembebanan.

Tabel 3.6 Strain Analisis Pada Bagian Atas Connecting joint Otomatis

\begin{tabular}{|c|c|}
\hline Kemiringan $\left({ }^{0}\right)$ & strain \\
\hline 0 & 0,000093 \\
\hline 10 & 0,000086 \\
\hline 20 & 0,000082 \\
\hline 30 & 0,000077 \\
\hline
\end{tabular}


Jurnal Dinamis USU, Vol. 9, No. 1 (Bulan, Tahun) | 06-21

\begin{tabular}{|c|c|}
\hline 40 & 0,000072 \\
\hline 50 & 0,000057 \\
\hline 60 & 0,000049 \\
\hline 70 & 0,000033 \\
\hline 80 & 0,00001658 \\
\hline 90 & 0,0000002903 \\
\hline
\end{tabular}

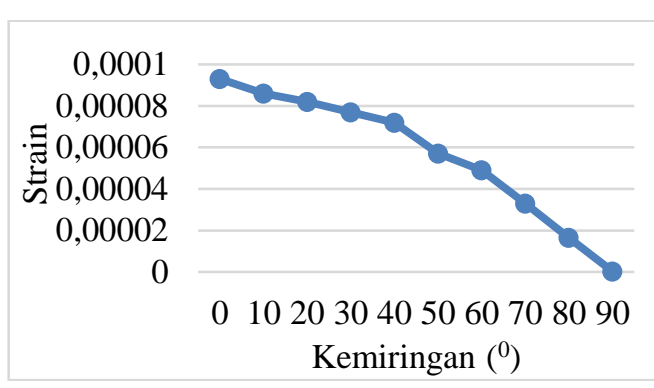

Gambar 3.8 Grafik Strain Analisis Pada Bagian Atas Connecting joint Otomatis

Tabel 3.7 Strain Analisis Bagian Atas Connecting joint Manual Pada Sudut 90 ${ }^{0}$

\begin{tabular}{|c|c|}
\hline $\begin{array}{c}\text { Kemiringan Connecting joint } \\
\text { Otomatis }\left({ }^{(}\right)\end{array}$ & Strain \\
\hline 0 & 0,000062 \\
\hline 10 & 0,000061 \\
\hline 20 & 0,000059 \\
\hline 30 & 0,000054 \\
\hline 40 & 0,000048 \\
\hline 50 & 0,00004 \\
\hline 60 & 0,000031 \\
\hline 70 & 0,000021 \\
\hline 80 & 0,00001047 \\
\hline 90 & 0,0000003561 \\
\hline
\end{tabular}

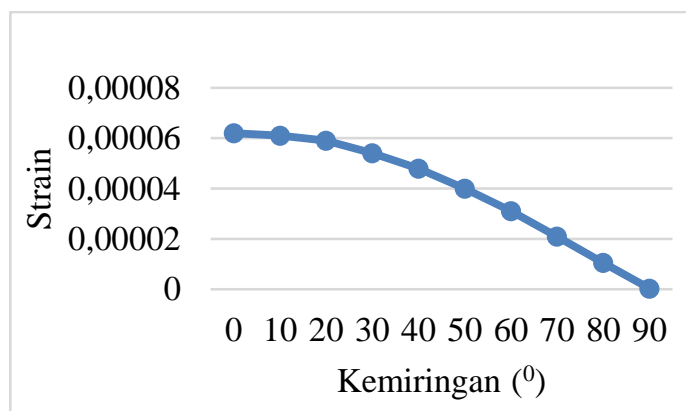

Gambar 3.9 Grafik Strain Analisis Bagian Atas Connecting joint Manual Pada Sudut $9^{0}$

Tabel 3.8 Strain Analisis Pada Bagian Atas Connecting joint Manual Kemiringan 60 ${ }^{0}$

\begin{tabular}{|c|c|}
\hline $\begin{array}{c}\text { Kemiringan Connecting joint } \\
\text { Otomatis }\left({ }^{0}\right)\end{array}$ & Strain \\
\hline 0 & 0,000115 \\
\hline 10 & 0,000114 \\
\hline 20 & 0,000111 \\
\hline 30 & 0,000106 \\
\hline
\end{tabular}




\begin{tabular}{|c|c|}
\hline 40 & 0,0001 \\
\hline 50 & 0,000092 \\
\hline 60 & 0,000082 \\
\hline
\end{tabular}

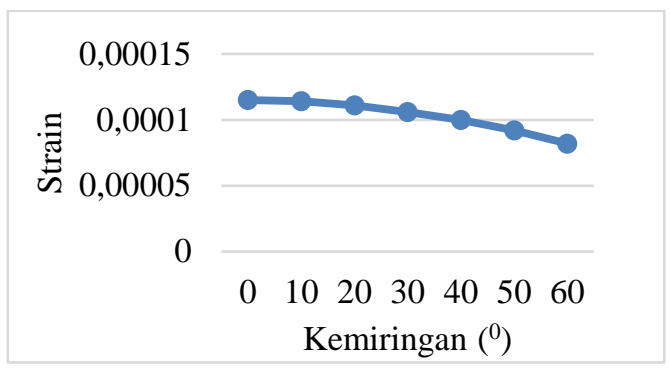

Gambar 3.10 Grafik Strain Analisis Pada Bagian Atas Connecting joint Manual Kemiringan $6^{0}$

Tabel 3.9 Strain Analisis Pada Bagian Atas Connecting joint Manual Dengan Kemiringan $3^{\circ}$

\begin{tabular}{|c|c|}
\hline $\begin{array}{c}\text { Kemiringan Connecting } \\
\text { joint Otomatis }\left(^{0}\right)\end{array}$ & Strain \\
\hline 0 & 0,00015 \\
\hline 10 & 0,00015 \\
\hline 20 & 0,00014 \\
\hline 30 & 0,00014 \\
\hline
\end{tabular}

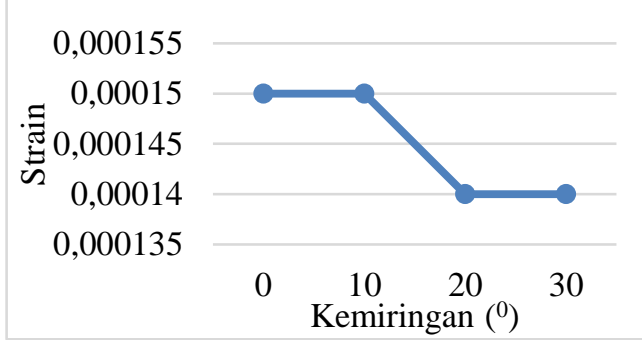

\section{Gambar 3.11 Grafik Strain Analisis Pada Bagian Atas Connecting joint Manual Dengan Kemiringan $3^{0}$}

Dari hasil simulasi dapat ditentukan strain terbesar dan terkecil pada bagian atas connecting joint manual, bagian atas connecting joint otomatis sebagai berikut:

1. Strain Tertinggi

a. Bagian atas Connecting joint otomatis Strain Tertinggi berada pada kemiringan $0^{0}$ yaitu 0,000093 .

b. Bagian Atas Connecting joint Manual

Strain tertinggi berada saat joint manual berada pada lubang ke 3 yaitu kemiringan $30^{\circ}$ dan pada saat bersamaan connecting joint otomatis memiliki kemiringan $0^{0}$ yaitu 0,00015 .

2. Stress Terendah

a. Bagian atas Connecting joint otomatis

Strain Terendah berada pada kemiringan $90^{\circ}$ yaitu 0,0000002903 .

b. Bagian Atas Connecting joint Manual

Strain tertinggi berada saat joint manual berada pada lubang ke 1 yaitu kemiringan $90^{\circ}$ dan pada saat bersamaan connecting joint otomatis memiliki kemiringan $90^{\circ}$ yaitu 0,0000003561 .

\subsubsection{Safety factor}

Dengan mendapatkan nilai safety factor dari titik yang telah ditentukan sebelumnya kita dapat mengetahui tingkat keamanan dari benda tersebut. Safety factor dinilai dari 0-15 dengan 0 nilai terendah dan 15 nilai tertinggi.

Tabel 3.10 Safety factor Pada Bagian Atas Connecting joint Otomatis

\begin{tabular}{|c|c|}
\hline Kemiringan $\left({ }^{0}\right)$ & Safety factor \\
\hline
\end{tabular}




\begin{tabular}{|l|l|}
\hline 0 & 15 \\
\hline 10 & 15 \\
\hline 20 & 15 \\
\hline 30 & 15 \\
\hline 40 & 15 \\
\hline 50 & 15 \\
\hline 60 & 15 \\
\hline 70 & 15 \\
\hline 80 & 15 \\
\hline 90 & 15 \\
\hline
\end{tabular}

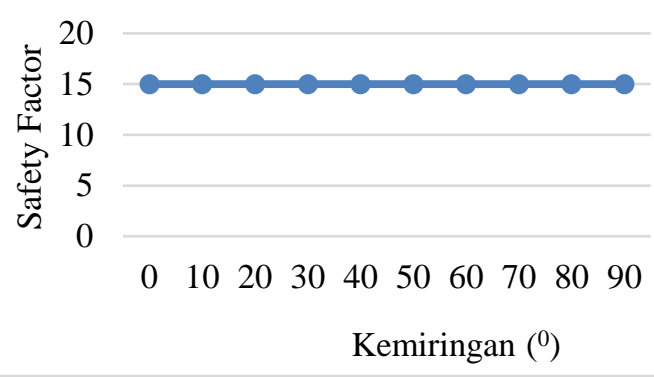

Gambar 3.12 Grafik Safety factor Pada Bagian Atas Connecting joint Otomatis

Tabel 3.11 Safety factor Bagian Atas Connecting joint Manual Pada Sudut 90 ${ }^{0}$

\begin{tabular}{|c|c|}
\hline $\begin{array}{c}\text { Kemiringan Connecting } \\
\text { joint Otomatis }\left({ }^{(}\right)\end{array}$ & Safety factor \\
\hline 0 & 15 \\
\hline 10 & 15 \\
\hline 20 & 15 \\
\hline 30 & 15 \\
\hline 40 & 15 \\
\hline 50 & 15 \\
\hline 60 & 15 \\
\hline 70 & 15 \\
\hline 80 & 15 \\
\hline 90 & 15 \\
\hline
\end{tabular}

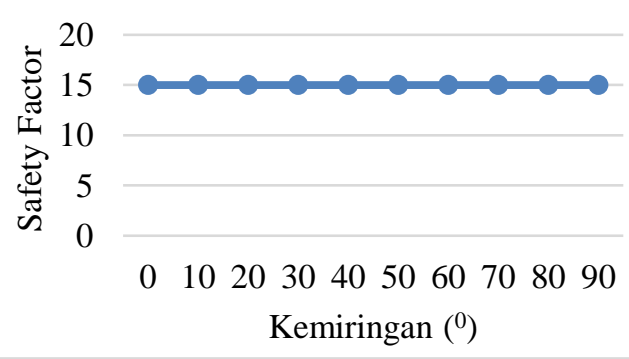

Gambar 3.13 Grafik Safety factor Bagian Atas Connecting joint Manual Pada Sudut 90 ${ }^{\circ}$

Tabel 3.12 Safety factor Pada Bagian Atas Connecting joint Manual Dengan Kemiringan $6^{\circ}$

\begin{tabular}{|c|c|}
\hline $\begin{array}{c}\text { Kemiringan } \\
\text { Connecting joint }\end{array}$ & Safety factor \\
\hline
\end{tabular}




\begin{tabular}{|c|c|}
\hline Otomatis $\left(^{0}\right)$ & \\
\hline 0 & 15 \\
\hline 10 & 15 \\
\hline 20 & 15 \\
\hline 30 & 15 \\
\hline 40 & 15 \\
\hline 50 & 15 \\
\hline 60 & 15 \\
\hline
\end{tabular}

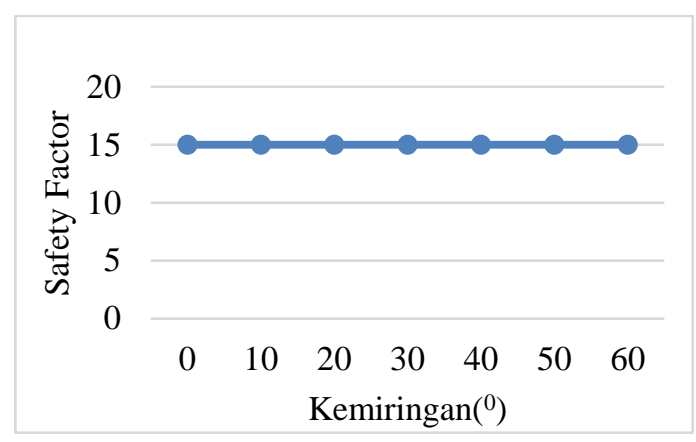

Gambar 3.14 Grafik Safety factor Pada Bagian Atas Connecting joint Manual Dengan Kemiringan $\mathbf{6 0}^{0}$

Tabel 3.13 Safety factor Pada Bagian Atas Connecting joint Manual Dengan Kemiringan $6^{\circ}$

\begin{tabular}{|c|c|}
\hline $\begin{array}{c}\text { Kemiringan Connecting joint } \\
\text { Otomatis }\left({ }^{0}\right)\end{array}$ & Safety factor \\
\hline 0 & 15 \\
\hline 10 & 15 \\
\hline 20 & 15 \\
\hline 30 & 15 \\
\hline
\end{tabular}

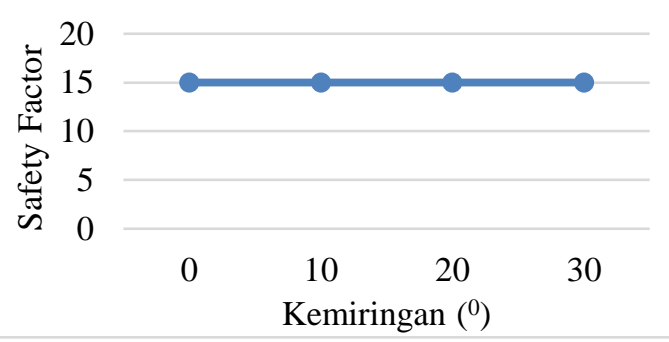

\section{Gambar 3.15 Grafik Safety factor Pada Bagian Atas Connecting joint Manual Dengan Kemiringan $3^{0}$}

Dari hasil simulasi dapat kita tentukan safety factor pada titik connecting joint manual dan titik connecting joint otomatis selalu berada pada titik maksimum.

\section{KESIMPULAN DAN SARAN}

\subsection{Kesimpulan}

Dari hasil pembahasan analisa pada connecting joint pada alat pemanen kelapa sawit, maka dapat ditarik kesimpulan sebagai berikut:

1. Semakin kemiringan joint mendekati $0^{0}$, Pola stress dari joint semakin meningkat, stress terbesar pada titik connecting joint manual sebesar 10,4 MPa dan pada connecting joint otomatis sebesar 6.6 MPa sedangkan tegangan izinnya $110 \mathrm{MPa}$ sehingga masih dalam keadaan aman. 
2. Semakin kemiringan joint mendekati $0^{0}$, pola strain dari joint juga akan semakin meningkat, strain terbesar pada titik connecting joint manual sebesar 0,00015 dan pada connecting joint otomatis sebesar 0,000093.

3. Semakin kemiringan joint mendekati $0^{0}$, pola safety factor dari joint tetap berada pada nilai maksimum sehingga masih dalam keadaan aman.

\subsection{Saran}

Dalam suatu penelitian pasti mengalami kendala dalam pengerjaannya, Adapun saran untuk penelitian yaitu:

1. Dalam menggambar usahakan ukuran sedetail mungkin dengan benda

2. Dalam melakukan simulasi usahakan agar load yang diinput dapat semaksimal mungkin agar hasil yang didapatkan lebih baik

3. Ada beberapa faktor yang dapat mempengaruhi hasil simulasi dan eksperimental berbeda, diantara nya ialah cuaca, maupun proses mate. Hal tersebut perlu diperhatikan dalam dalam pengujian untuk mendapat hasil yang maksimal.

\section{REFERENSI}

[1] C.R. Nave, Department of Physics and Astronomy, Georgia State University. $\quad$ How does an electric motor work? In: Hyperphysics, Electricity and Magnetism. 2005

[2] Giancoli, Douglas C. 2001. Fisika/Edisi Kelima Jilid 1. Jakarta : Erlangga.

[3] Jatmiko, S., Saptadi 2011. Analisa Kekuatan Deck Tongkang Muatan Tiang Pancang 750 DWT Dengan Software Berbasis Metode Elemen Hingga. Fakultas Teknik Perkapalan, Universitas Diponegoro. Semarang.

[4] AK, Candra. 2016. Analisis Tegangan, Defleksi, Pemeriksaan Kebocoran Pada Flange Perbandingan Gaya Dan Momen Pada Nozzle Pipa Discharge Feed Water Takuma Boiler Milik PT. Suparma. Skripsi. Fakultas Teknik Universitas Muhammadiyah Yogyakarta

[5] Popov, E.P. 1978.Mechanics of Material, 2nd edition, Prentice-Hall, Inc., Englewoood Cliffs. New Jersey. USA Kubota, S. \& Takigawa. 2001. Diesel Engine Performance. Prentice Hall, New Jersey.

[6] Satria, Dhimas. 2014. Dasar-Dasar Perancangan Mesin. Terbita: Untirta Press. 